\section{SCORECARD}

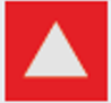

Hydrogen

Hydrogen has been unfairly maligned as the

cause of the Hindenburg airship disaster, according to Martin Chávez, mayor of Albuquerque. In the interests of promoting hydrogen fuel, he has called on the US government to pardon the gaseous element.

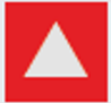
Superconductors The authors of a citation study thatp redicted no more papers in high-temperature superconductivity after 2015 seem to have yielded to the wrath of physicists in the field (see Nature 443, 376;2006). They have now removed the extrapolation to zero from theirpreprint.

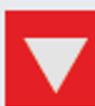

\section{Canada}

It is usually considered that Canada is more environmentally friendly than the United States. But during fishing negotiations at the United Nations last week, Canada became the bad guy.Itrefused to signup to aUS-backed ban on bottom

s trawling, which devastates fish 8 populations and the oceanfloor.

\section{ZOO NEWS}

\section{Babygorillas}

Twoorphaned gorillas raised by the John Aspinall Foundation (JAF) and released into the wild in the Republic of Congo have both been spotted with young offspring - only the second and third recorded births to reintroduced gorillas. JAF researchers are now planning DNA tests of the males in the group, toidentify who the fathersare.

\section{Nano spiders}

Readers with arachnophobia may wish to avert their eyes. Researchers have created 'molecular spiders' with legs just 10 nanometres long. Biochemist MilanStojanovic hopes the spiders could perform certain tasks: "We could have a simple predator-prey system in which one would try tocleave the legs of the other."

\title{
Hard-hitting endeavour captures Ig Nobel
}

\section{BOSTON}

When Ivan Schwab first learned that he was slated to win an Ig Nobel prize for explaining why woodpeckers don't get headaches, his response was perhaps predictable for a man whose past had come back to haunt him: he denied everything.

"I didn't do the work," Schwab, an ophthalmologist at the University of California, Davis, told the event's organizer after being informed of the dubious honour in store for him. Ig Nobel prizes are given for "achievements that make people laugh, and then make them think". Schwab gave credit instead to Philip May, a former psychiatry professor at the University of California, Los Angeles, who died in 1986. A deal was soon reached: Schwab agreed to share the 2006 Ornithology prize with May for research initiated by May and associates in 1976 and taken up by Schwab a quarter of a century later.

To May, the woodpecker represented a unique "experiment in Nature" and a chance to understand how an animal could continually use its head as a battering ram without sustaining headaches, concussions or other brain injuries.

A pileated woodpecker may strike its beak against a tree 12,000 times a day for the purposes of feeding, nest construction, ritual drumming (to claim territory and attract mates), and even to relieve tension. They peck at rates of up to 20 times a second — each blow is comparable to striking a wall, face-first, at 25 kilometres an hour. This results in deceleration forces of about $1,200 \mathrm{~g}$, which is hundreds of times more than astronauts endure. Given the ill effects of headbanging seen in humans, May wondered why the countryside was not “littered with dazed and dying woodpeckers".

Clearly, woodpeckers do not get headaches or serious head injuries, May reasoned, or they would stop pecking. So how do they prevent it? After dissecting the heads and beaks of two woodpeckers (which were compared with similar toucan samples) and analysing high-speed photographs of live woodpecker strikes, May and his colleagues advanced several explanations (P. R. May et al. Lancet i (7957), 454-455; 1976; Arch. Neurol. 36, 370-373; 1979).

The woodpecker brain has relatively little cerebrospinal fluid, reducing the transmission of shock waves, and it is tightly packed in

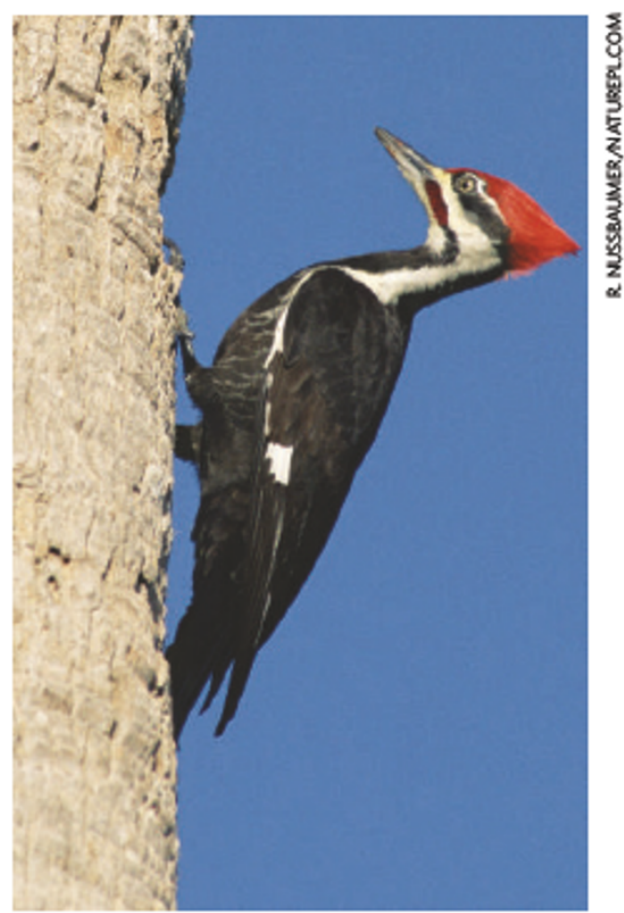

Striking stat: the pileated woodpecker hitsits beak against a tree around 12,000 times a day.

dense, spongy bone that keeps internal movements to a minimum. Muscles encircling the skull serve as shock absorbers, "holding the bill in resilient rigidity".

Like boxers, woodpeckers tense their neck muscles before absorbing a blow. And their drilling trajectory is essentially linear, with little or no rotation of the head, to avoid shearing forces. A third eyelid closes a millisecond before each strike to secure and shield the eye.

Schwab, a bird enthusiast since childhood, read May's 1976 Lancet article and later papers with keen interest. On occasion, he mentioned the woodpecker example in ophthalmology classes and at conferences, citing the potential for retinal damage, and always engaged his audience. Yet he yearned to do more on the subject.

He got his chance in 2000, when he became an editor of the British Journal of Ophthalmology. In 2002, Schwab put a woodpecker on the journal's cover and wrote an essay presenting May's findings and discussing anatomical features that might provide further protection, as a result of dissections and CT scans he had performed of a pileated woodpecker head 
(I. R. Schwab Br. J. Ophthalmol. 86, 843; 2002). But Schwab's main objective was to bring attention to May's neglected work. "We can't all win Nobel prizes," he says. "But we can look at the world around us and ask questions, just as May did." In his own field, Schwab asks, for example, why polar bears don't get ultraviolet keratopathy - sunburn of the eyes. How can a jellyfish, which lacks a brain, process the visual information it gets from its eyes? Why do scallops have hundreds of eyes and giant clams thousands? Questions such as these, says Schwab, are "the basis of discovery".

For that reason, Schwab says he is proud to be associated with May's research and was delighted to receive an Ig Nobel on his behalf at the ceremony held at Harvard University on 5 October (see 'The Ig Nobel winners' circle'). He certainly got into the spirit of things, attending the festivities in a woodpecker headdress. As for his initial reluctance, Schwab explains: "I was embarrassed to receive an Ig Nobel prize for work I did not do." In that respect, he stands out from previous winners, who were embarrassed to receive IgNobels for work they did do.

Steve Nadis

\section{The Ig Nobel winners' circle}

On5 October, more than 1,000 people jammed into Harvard's Sanders Theatre to witness the Ig Nobel prize ceremony. Scientists from across the globe gathered to receive awards for of fbeat research that would never get through the door at Stockholm. Here are a few winners.

- Acoustics Lynn Halpern of Harvard Vanguard Medical Associates and Randolph Blake of Vanderbilt University accepted the award for experiments investigating why people hate the sound of fingernails scraping on a blackboard. Blake speculated that the sound resembles "non-human primate warning calls" and triggers a vestigial fear response. To illustrate the point, the seven Nobel laureates present reproduced the offending sound on individual blackboards - after donning protective earmuffs. - Biology Bart Knols and Ruurd de Jong of Wageningen Agricultural University in the Netherlands captured their award for showing that female malaria mosquitoes find the smell of Limburger cheese and human feetequally ap pealing. A synthetic blend of the chemicals involved might help fight malaria by luring the insects away from people. In his acceptance speech, Knols apologized to his wife for forcing her to sit naked in a net with blood thirsty mosquitoes, as he recorded where they bit. - Literature Princeton psychologist Daniel Oppenheimer triumphed for a study, published in Applied Cognitive Psychology, entitled "Consequences of erudite vernacular utilized irrespective of necessity: problems with using long words needlessly". Oppenheimer's acceptance speech: "My research shows that conciseness is interpreted as intelligence. So thank you."

-Medicine University of Tennessee's Francis Fesmire won for being, in his words, "the first person to terminate hiccups with digital rectal massage". A trio from Bnai Zion Medical Center in Haifa, Israel, shared the award. At first, Fesmire confessed, hewas disappointed to win an Ig Nobel rather thana real one. Buthis son cheeredhim up: "It'slike winning a Darwin Award, and you don'thave to die." 